\title{
Cutaneous wound healing: canine allogeneic ASC therapy
}

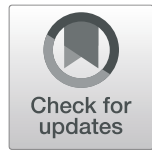

Nathaly Enciso ${ }^{1,2}$, Luis Avedillo ${ }^{1,2}$, María Luisa Fermín ${ }^{1,3}$, Cristina Fragío ${ }^{1,3}$ and Concepción Tejero ${ }^{1,2^{*}}$ (D)

\begin{abstract}
Background: Wound healing is a complex biological process comprised of a series of sequential events aiming to repair injured tissue. Adult mesenchymal stem cells (MSCs) have been used in cellular therapy in preclinical animal studies; a promising source of MSCs is adipose tissue (AT). In this paper, we evaluated the clinical value and safety of the application of cultured allogenic MSCs from AT for acute and chronic skin wound healing in a canine model.

Methods: Twenty-four dogs of different breeds between 1 and 10 years of age with acute and chronic wounds were studied. Morphology of the wounded skin was monitored for changes over time via serial photographs and histopathological studies.

Results: The percentage of the wounds that exhibited contraction and re-epithelialization were significantly different between wounds treated with adipose mesenchymal stem cells (ASCs) and control wounds; this effect was observed in both acute and chronic conditions. At 90 days, re-epithelization of acute and chronic wounds reached more than $97 \%$. Histopathological study revealed a reduction in inflammatory infiltrate and the presence of multiple hair follicles on day 7 after treatment with ASCs, promoting epidermal and dermal regeneration. To guarantee the safety of our treatment, we determined the serum levels of cytokine markers in our patients. ASC treatment upregulated granulocyte-macrophage colony stimulating factor (GM-CSF) at the gene level, which may contribute to the recruitment of cells that participate in skin repair to the site of injury.

Conclusions: The development of an allogenic ASC therapy to improve wound healing in a canine model could have a clinical impact in human treatment.
\end{abstract}

Keywords: Adipose mesenchymal stem cells, Canine cutaneous wounds, Regenerative medicine, ASC therapy

\section{Background}

Adult mesenchymal stem cells (MSCs) have been widely used in regenerative medicine in both in vitro and in vivo preclinical research and clinical trials. MSCs have high proliferation potential, self-renewal abilities, and multilineage differentiation capabilities enabling them to produce cells of mesodermal and non-mesodermal

\footnotetext{
* Correspondence: contejor@ucm.es

1"Experimental Hematology" UCM-Research Group, Veterinary Faculty, Complutense University of Madrid, Avda Puerta de Hierro s/n, 28040 Madrid, Spain

${ }^{2}$ Department of Biochemistry and Molecular Biology, Veterinary Faculty, Complutense University of Madrid, Avda Puerta de Hierro s/n, 28040 Madrid, Spain

Full list of author information is available at the end of the article
}

origin; these cells are able to secrete soluble factors that stimulate the migration, mitosis, and differentiation of local stem cells. These characteristics make MSCs interesting tools for tissue engineering and regeneration in human clinical trials.

In recent years, an increasing number of studies have arisen, with different approaches like comparing the efficacy of allogeneic and autologous MSCs, the origin of the sample, the method of MSC isolation [1-4], and the determination of the dose and adjuvant products $[5,6]$, because these therapies are not yet fully standardized. In the European Union, the use of these treatments has been possible because cell therapy products have been 
considered medicinal products since 2003, according to legislation through Directive 2003/63/EC [7].

A major advance has been the development of MSC therapies to treat a variety of human diseases $[8,9]$. The protocols have been developed due to the fact that MSCs possess unique characteristics, such as hypoimmunogenicity, immunomodulation, and antiinflammatory properties, which make them interesting and safe tools to be explored for possible therapeutic uses.

A number of studies confirmed the existence of MSCs in canine adipose tissue as well as in bone marrow [1013]. In preclinical animal studies, a promising source of MSCs has been found to be adipose tissue (AT). In fact, adipose mesenchymal stem cells (ASCs) are being used, especially in small breeds where the amount of bone marrow that can be harvested is limited and the collection is more laborious and painful.

In view of future therapeutic applications, the study of the expression of specific differentiation-related genes is a pivotal prerequisite. Recent studies have explored the role of transcription factors, including Runx2, Sox9, and PPAR $\gamma$, in the differentiation of MSCs [14-17]. The overexpression of a single transcription factor in MSCs may promote transdifferentiation into a specific cell lineage, which could then be used for the treatment of some diseases. In this context, it is crucial to use stable housekeeping genes (HGs) for normalization of RT-qPCR data to obtain validated and comparable results $[18,19]$. Wound healing is a complex biological process comprised of a series of sequential events aiming to repair injured tissue [20-22]. During these processes, growth factors, cytokines, matrix metalloproteases, and angiogenesis factors play an important role in processes like inflammation, formation of granulation tissue, re-epithelialization, matrix formation, and re-modeling [23].

The cellular and molecular mechanisms supporting tissue repair are still poorly understood, and current therapies are limited [24-27]. Previous studies of MSC transplantation in animal models and human patients have demonstrated improved therapeutic effects in terms of rapid wound healing and improved dermal regeneration [7, 28-33]. After systemic administration, MSCs are also capable of migrating to and engrafting in sites of inflammation where they exert local functional effects in the resident tissue [34-38]. In addition, MSCs regulate immune and inflammatory responses and can have a reparative effect through paracrine signaling by releasing biologically active molecules that affect cell migration, proliferation, gene expression, and survival of the surrounding cells [33, 39]. Studies have demonstrated that treatment with MSCs has significant immunomodulatory effects during wound healing [40, 41]. This immunomodulatory consequence on the host makes them a suitable candidate for allogeneic transplantation. Allogenic MSC administration has the advantage of prompt preparation of material, and it does not depend on the health status of the patient [42-44].

In this context, the dog is considered an ideal research model because it is a large animal that shares the same environment as humans and develops many diseases that occur in humans, and dog's immune system is known to be similar to those of humans [45, 46]. In addition, wound healing has been studied using dogs as a translational model for both veterinary and human applications [47].

Identification of the positive and adverse effects of allogenic MSC transplantation for skin wound healing using a canine model is needed prior to its use in human clinical trials.

In this paper, we evaluated the clinical value and safety of the application of cultured adipose allogenic mesenchymal stem cells for treating acute and chronic skin wound healing in a canine model. We estimated serum levels of cytokine markers to ensure the welfare and security of our treatment. Wound skin morphology and changes over time were monitored via serial photographs and histopathological studies, and wound closure areas were estimated. In addition, key transcription factors involved in the differentiation of mesenchymal stem cells were evaluated.

We hypothesized that ASC-treated wounds could have improved outcomes compared to untreated controls through local mRNA expression of several factors related to cutaneous wound healing.

The research presented in this study can direct us toward improved therapeutic protocols.

\section{Methods}

Twenty-four dogs of different breeds that were between 1 and 10 years of age that presented with acute and chronic wounds produced by sports activities as well as household injuries were included in this study, wounds penetrating into the subcutaneous tissue without muscular tissue affection. Wounds produced by bites were excluded. Eight healthy dog skin biopsies were taken for RT-qPCR analysis. All animal experiments should comply with the Animal Research: Reporting In Vivo Experiments (ARRIVE) guidelines and were approved by the ethical committee of our institution (approval no. 08/2017). Dog owners provided informed consent for the treatment. The study was performed on 24 dogs divided into four groups: group I, 6 dogs with acute skin wounds treated with conventional treatment; group II, 10 dogs with acute skin wounds treated with ASCs; group III, 4 dogs that had chronic skin wounds for 1-2 months treated with conventional treatment; and group IV, 4 dogs that 
had chronic skin wounds for 2-3 months that were then treated with ASCs.

\section{Treatment protocols}

All dogs were treated every $48 \mathrm{~h}$ for 8 days with $15 \mathrm{mg} /$ kg IM amoxicillin trihydrate (Bivamox ${ }^{\bullet}$ L.A.; Boehringer Ingelheim España, S.A.) and $5 \mathrm{mg} / \mathrm{kg}$ every $24 \mathrm{~h}$ PO enrofloxacin (Ganadexil enroflocaxino; Industrial Veterinaria, S.A., Barcelona, Spain). After 3 days with this treatment protocol, one dose of $3 \times 10^{7}$ allogeneic ASCs in phosphate-buffered saline (PBS; as a vehicle) was injected intradermally around wounds with an area of up to $10 \mathrm{~cm}^{2}$, and two doses of $3 \times 10^{7}$ cells were injected in wounds with an area that was greater than $10 \mathrm{~cm}^{2}$. The first injection took place at day 3 and the second dose at day 10 after wounding. Groups I and III received conventional treatment with an ointment containing Centella asiatica extract and neomycin (Blastoestimulina ${ }^{\circ}$ 1\%; Almiral S.A., Barcelona, Spain) until the wound was healed.

Isolation, expansion, and differentiation of adipose MSCs ASCs were obtained as previously described by Enciso et al. [10]. Briefly, omental adipose tissue was obtained from healthy donor female dogs that were undergoing elective sterilization, and ASCs were consecutively isolated and cultured in DMEM that contained 10\% canine serum (dog serum was derived from pooled batches obtained from whole blood collected in tubes free of anticoagulant, centrifuged at $2000 \mathrm{rpm}$ for $10 \mathrm{~min}$, and filtered through $0.2 \mu \mathrm{m}$ ) and $1 \%$ antibiotic; the supernatant obtained after 3 weeks from the culture was considered conditioned medium (CM) and was frozen at $80^{\circ} \mathrm{C}$. ASCs used for injection were cultured in the Luria-Bertani medium (Scharlab S.L. Barcelona, Spain) to evaluate sterility. Before using the ASCs therapeutically, cells were analyzed by flow cytometry to confirm that they were positive for CD90 and negative for CD34, $\mathrm{CD} 45$, and $\mathrm{MCH}-\mathrm{II}$ as previously reported [10, 48]. Their ability to adhere to plastic and their fibroblast-like morphology were confirmed. These criteria of MSC were defined by the International Society for Cellular Therapy [49].

\section{Differentiation}

The multipotentiality of ASCs was determined by analyzing their capacity to differentiate into three lineages.

\section{Osteogenic differentiation}

Osteogenesis differentiation medium (StemPro, Gibco) was used according to the manufacturer's instructions. ASCs were cultured for 21 days, the medium was changed every 3rd day, and differentiation was assessed by von Kossa staining. For this process, the cells were fixed with $4 \%$ formaldehyde solution for $30 \mathrm{~min}$, which was followed by rinsing with PBS and incubation with $2.0 \%$ silver nitrate in the dark for $30 \mathrm{~min}$. After rinsing with distilled water and air drying, the cells were exposed to UV light for $60 \mathrm{~min}$ to develop calcium phosphate precipitate. The cells were washed several times with PBS and were visualized under a light microscope. Brown staining indicated the deposition of calcium phosphate precipitate by osteoblasts.

\section{Chondrogenic differentiation}

Chondrogenesis differentiation medium (StemPro, Gibco) was used according to the manufacturer's instructions. ASCs were cultured for 14 days, the medium was changed every 3rd day, and the differentiation was assessed by Alcian blue staining. The cells were fixed with $4 \%$ formaldehyde for $30 \mathrm{~min}$ and then were washed with PBS. Then, $1 \%$ Alcian blue, which was prepared in $0.1 \mathrm{~N} \mathrm{HCl}$, was added for $30 \mathrm{~min}$ incubation. Finally, the ASCs were washed with $0.1 \mathrm{~N} \mathrm{HCl} \mathrm{pH} \mathrm{1.0,} \mathrm{and} \mathrm{distilled}$ water was added. Blue staining indicated chondrocyte synthesis of proteoglycans.

\section{Adipogenic differentiation}

An adipogenesis differentiation kit (StemPro, Gibco) was used according to the manufacturer's instructions. ASCs were cultured for 21 days, the medium was changed every 3rd day, and differentiation was assessed by the presence of lipid droplets that were visualized after staining with oil red $\mathrm{O}$ solution. The cells were fixed with $10 \%$ formal calcium fixative for $60 \mathrm{~min}$, and then, they were washed with PBS and then with $70 \%$ ethanol. Addition of oil red $\mathrm{O}$ solution was followed by rinsing the cells with $70 \%$ ethanol and then with tap water. Red staining indicated the presence of lipids.

\section{Transwell assay}

Migration assays were conducted using $8 \mu \mathrm{M}$ Transwell plates (Corning). ASCs at passage 3 were seeded in triplicate at a density of $3 \times 10^{3}$ cells/Transwell in DMEM in the upper chamber of Transwell plates. We evaluated the following solutions: DMEM, DMEM $+10 \%$ canine serum, DMEM + granulocyte-macrophage colony stimulating factor (GM-CSF) (100 or $200 \mu \mathrm{g} / \mathrm{ml})$, and conditioned medium $(\mathrm{CM})$. The cells were placed in the lower chamber to induce cell migration. After $8 \mathrm{~h}$, cells on the top of the Transwell were removed, and cells that had migrated to the lower surface were fixed by incubation with cold $70 \%$ ethanol $\left(4^{\circ} \mathrm{C}\right.$ ) for $10 \mathrm{~min}$ (room temperature), and then, they were incubated with the May-Grünwald-Giemsa staining solution. Images of cells were captured using an inverted microscope (Leica) and were subsequently manually quantified. 


\section{Multiplex assays}

Peripheral blood from each dog was collected in sterile tubes for cytokine analysis. Serum was separated by centrifugation and then was stored at $-80^{\circ} \mathrm{C}$. Serum samples were batch analyzed at the conclusion of the study. Bead-based multiplex assays measure multiple cytokines from the same sample at the same time. Analyses were performed according to the manufacturer's instructions, with internal quality control using a Milliplex MAP Canine kit with Luminex technology (Immunology Multiplex Assay). The following cytokines were measured: granulocyte-macrophage colony stimulating factor (GMCSF), interleukin-6 (IL-6), interleukin-7 (IL-7), interleukin-8 (IL-8), interleukin-10 (IL-10), interleukin15 (IL-15), interleukin-18 (IL-18), interferon $\gamma$-inducible protein-10 (IP-10), keratinocyte chemoattractant (KC), monocyte chemoattractant protein-1 (MCP-1), and tumor necrosis factor $\alpha$ (TNF $\alpha)$.

\section{Clinical evaluation}

Lesion progression was documented using a ruler to measure wound size. Photographs were taken at 7, 30, and 90 days post-treatment. The percent wound size and epithelization were evaluated according to the criteria proposed by Farghali et al. [50].

\section{Skin biopsies for histological analysis and gene expression}

On day 7 after initiation of treatment, 4-mm-diameter punch biopsies of the ASC-treated wound, conventionally treated wound, and normal skin were taken from the edge of wounds for histopathological study and RTqPCR analysis. Formalin-fixed and paraffin-embedded skin biopsy samples were stained with hematoxylin and eosin $(\mathrm{H} \& \mathrm{E})$ and were examined under a light microscope (Leitz Laborlux S).

\section{RT-qPCR analysis}

Total RNA was extracted from $10^{6}$ cultured ASCs using an RNeasy ${ }^{\bullet}$ Mini kit (Qiagen, Hilden, Germany) according to the manufacturer's protocol. Total RNA from tissue was extracted using TRIzol (Invitrogen); briefly, 50 $\mathrm{mg}$ of tissue was homogenized and incubated for $5 \mathrm{~min}$ at $30^{\circ} \mathrm{C}$, and then, chloroform was added and incubated with the homogenized tissue at $30^{\circ} \mathrm{C}$ for $3 \mathrm{~min}$. The sample was centrifuged for $15 \mathrm{~min}$ at $12,000 \times g$ at $4{ }^{\circ} \mathrm{C}$, and the aqueous phase containing the RNA was transferred to a new tube and treated with RNeasy Mini kit (Qiagen) according to the manufacturer's protocol. Reverse transcription was performed with $1 \mu \mathrm{g}$ of total RNA and a "High Capacity RNA-to-cDNA Kit" (Applied Biosystems, Foster City, CA, USA) according to the manufacturer's protocols. RT-qPCR was performed with a "Power SYBR ${ }^{\odot}$ Green PCR Master Mix" (Applied
Biosystems) on QuantStudio 12k Flex equipment (Applied Biosystems). All nucleotides were purchased from Metabion International AG (Munich, Baviera, Germany). A set of primers was designed to amplify the following canine genes: TBP, RUNX2, SOX9, PPARG, MMP2, GMCSF, VEGFA, and $I L-10$.

Primer designs were based on the Primer3 program [51] and the National Center for Biotechnology Information Blast Search Program (http://www.ncbi.nlm.nih.gov/).

The primers were as follows:

\begin{tabular}{ll}
\hline Genes & Primer sequences \\
\hline TBP & Forward: 5'-CCGTCTATCTGAACTGGGAAA-3' \\
& Reverse: 5'-AAGGGTCATGAGTGGCATGT-3' \\
RUNX2 & Forward: 5'-TGAGCACCGAAGAACAACTG-3' \\
& Reverse: 5'-GCTGCTGCTGCTACACTGAC-3' \\
SOX9 & Forward: 5'-AGCGAACGCACATCAAGAC-3' \\
& Reverse: 5'-GAGGCTGAAGGGGCTGTAG-3' \\
PPARY & Forward: 5'-TGGCAAAGAGCTGAGAGGAC-3' \\
& Reverse: 5'-AAAATCAAGTTCAAACACATCACC-3' \\
MMP2 & Forward: 5'-GAGCGAGGGTACCCCAAG-3' \\
& Reverse: 5'-GCTCCAATTAAAGGCAGCAT-3' \\
GM-CSF & Forward: 5'-TCTCTGAAGTGTTTGACCCTGA-3' \\
& Reverse: 5'-CAGGCCCTCCTTGTACAGC-3' \\
VEGFA & Forward: 5'-CGTGCCCACTGAGGAGTT-3' \\
& Reverse: 5'-GCCTTGATGAGGTTTGATCC-3' \\
IL-10 & Forward: 5'-CAGGTGAAGAGCGCATTTAGT-3' \\
& Reverse: 5'-TCAAACTCACTCATGGCTTGG-3'
\end{tabular}

The PCR protocol started with one cycle at $95^{\circ} \mathrm{C}$ for $10 \mathrm{~min}$ and continued with 40 cycles of $95^{\circ} \mathrm{C}$ for $15 \mathrm{~s}$ and $60{ }^{\circ} \mathrm{C}$ for $1 \mathrm{~min}$. Assays were performed in duplicate, and the average threshold cycle number $(\mathrm{Ct})$ for each tested gene and condition was used to quantify the relative gene expression according to the $\Delta \Delta \mathrm{Ct}$ method. Normalization was performed using $T B P$ as a housekeeping gene $[18,52]$. To confirm the specificity of the primers used, the obtained amplicons were compared with the target gene sequences available in the GenBank/EMBL databases using Blast software (http://www.ncbi.nlm.nih.gov/BLAST).

\section{Statistic}

The results were analyzed using the software programs SPSS 25 (IBM Corporation, Endicott, NY, USA) and Graph Pad Prism version 6. Normally distributed data were assessed using the Kolmogorov-Smirnov and Shapiro-Wilk tests. Gene expression along differentiation and gene expression in skin wound by RT-qPCR were evaluated by ANOVA post-Bonferroni test. 
Migration was evaluated by comparing the number of ASCs between groups with ANOVA post-Dunnett test. Serum cytokine levels were evaluated with ANOVA post-Tukey's multiple comparisons test between dogs undergoing conventional treatment or ASC treatment at 7 and 30 days post-treatment. The percentage of regenerated area of acute and chronic wounds after conventional and ASC treatment was calculated with ANOVA post-Bonferroni test. All are expressed as the mean \pm SD. Differences were considered significant when $p<0.05$.

\section{Results}

\section{Differentiation and transmigratory capacity of ASC}

Trilineage differentiation capacity of ASCs is shown in Fig. 1a. When evaluating the transcription factors, we observed that PPARy showed a 2-fold increase in adipogenic differentiation compared to ASC, while SOX9 and RUNX2 did not show this augment in their representative linages; however, their increases were significant $(p<0.0001)$ with respect to other lineages (Fig. 1b) [14]. The values were normalized to the TBP gene and were compared to ASCs.

The effect of GM-CSF on hematopoietic stem cell migration is well known, so we evaluated this effect on ASCs. At a dose of $200 \mathrm{ng} / \mathrm{ml}$, there was an increase in the number of migrating cells compared to the $100 \mathrm{ng} / \mathrm{ml}$ treatment group. Interestingly, conditioned medium induced ASC migration effects that were similar to those following treatment with GMCSF $(200 \mathrm{ng} / \mathrm{ml})$. Furthermore, both GM-CSF $200 \mathrm{ng} /$ $\mathrm{ml}$ and conditioned medium produced significantly different $(p<0.05)$ migration results from those

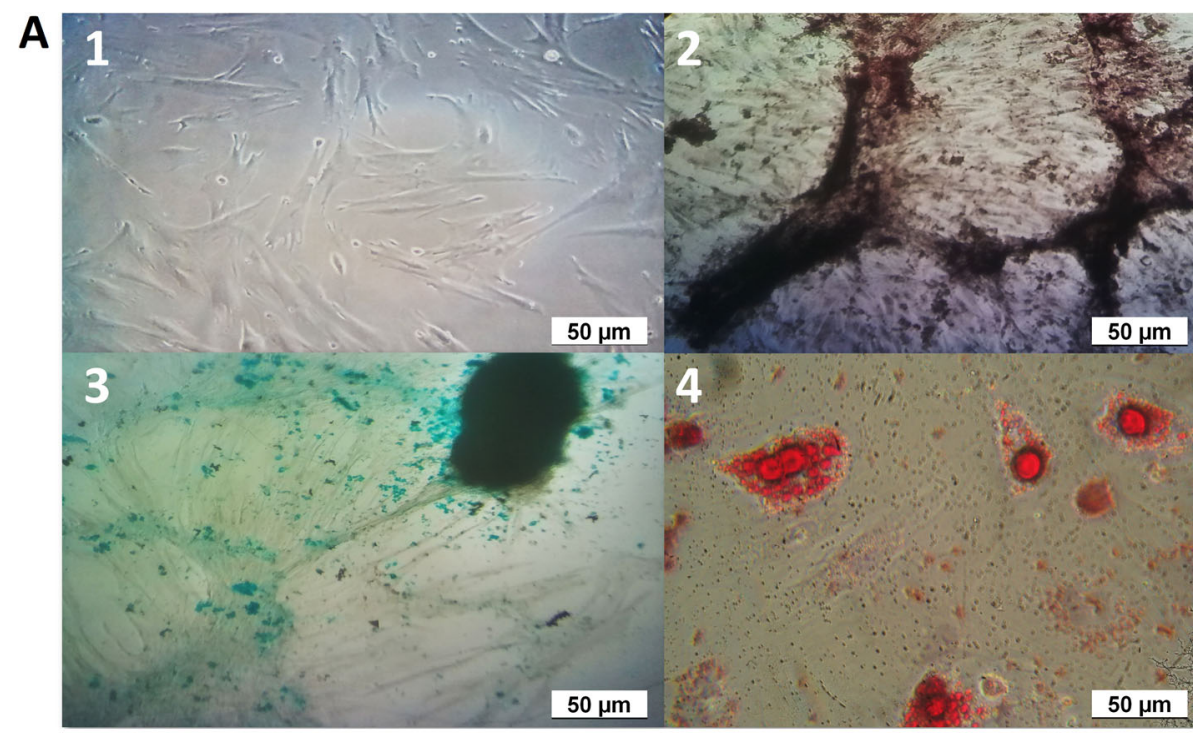

B.

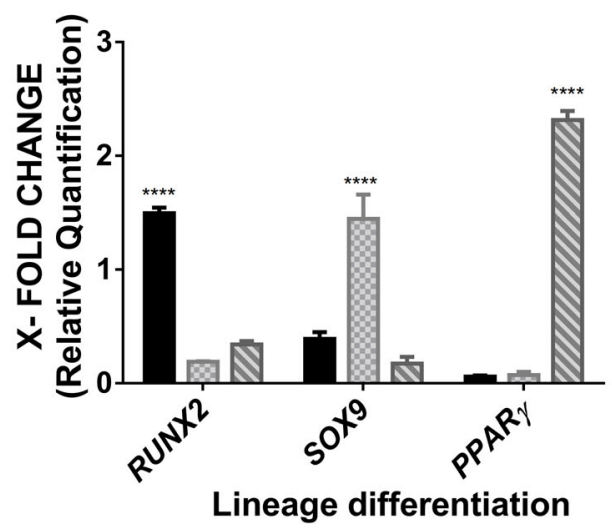

Osteogenic

Condrogenic

Adipogenic

\section{Lineage differentiation}

Fig. 1 Differentiation of canine adipose-derived mesenchymal stem cells (ASCs) into osteocyte, chondrocyte, and adipocyte lineages. a Representative photographs. ASCs from the 3rd passage showed spindle-shaped fibroblastic cell morphology (1). After 3 weeks, ASCs

differentiated according to the conditioned medium added. Cells underwent von Kossa staining for osteogenic lineage (2), Alcian blue staining for chondrogenic lineage (3), and oil red $\mathrm{O}$ staining for adipogenic lineage (4) (bar length $=50 \mu \mathrm{m}$ ). b RT-qPCR analysis of transcription factors in the differentiation of ASCs. Data represent mean fold change values in genes \pm SD compared to ASCs. ${ }^{* * * * A}$ statistically significant difference of $p<0.0001$ of each transcription factors representative of a specific lineage with respect to the genes of other lineages. $n=3$ different experiments 
observed in the cells grown in DMEM. Our data represent the mean \pm SD (Fig. 2).

\section{Evaluation of treatment safety by quantifying cytokine levels in serum}

To estimate potential adverse events associated with the use of ASC treatment, we evaluated incidents according to the grading system of the veterinary cooperative oncology group [53]. We measured the cytokine profiles at 7 and 30 days post-treatment in sera from six patients treated with ASCs and four patients that underwent conventional treatment, and none of them did present adverse events during the study. Cytokine values in the serum were similar in patients with conventional and ASC treatment, except for IL8, which had a higher value in patients treated with ASCs than it did in the conventional treatment and was also significantly different $(p<0.01)$ at 7 and 30 days (Fig. 3); however, the IL8 mean value obtained at day $30(3329 \mathrm{pg} / \mathrm{ml})$ was within the normal range for healthy dog serum quantified by O'Neill et al., Kjelgaard-Hansen et al., and Safra et al. [54-56].

\section{Skin regeneration of cutaneous wounds by ASC therapy}

The areas of the wounds were measured on the first, seventh, thirtieth, and ninetieth days after treatment. Wound contraction and regenerative area were calculated and expressed as percentages (Fig. 4a). The regenerated area in patients with acute wounds treated with ASCs at 7,30 , and 90 days was significantly different $(p<0.0001)$ from that of the time-matched conventional treatment (Fig. 4b (1)). Patients with chronic wounds treated with ASCs were significantly different at $7(p<0.001), 30$, and 90 days $(p<0.0001)$ from those treated with the conventional treatment (Fig. 4b (2)). On the other hand, the percentages of regenerated area between acute and chronic wounds in patients treated with ASCs were significantly different at $7(p<0.0001)$ and $30(p<$ $0.001)$ days, while on the ninetieth day, the regenerated area was similar (Fig. 4b (3)). In addition, we have analyzed data of acute wounds that have received one or two doses, obtaining the same significant difference $p<0.0001$ (data not shown).

Re-epithelization was illustrated by photographs taken on the zero (Fig. 5a (1 and 4), b (1 and 4)), seventh (Fig. 5a (2 and 5), b (2 and 5)), and ninetieth (Fig. 5a (3 and 6), b (3 and 6)) days post-treatment of acute and chronic wounds, respectively. On day 7 , acute and chronic wounds treated with ASCs (Fig. 5a (5), b (5)) displayed accelerated skin closure compared with conventional wounds (Fig. 5a (2), b (2)). On day 90, wounds with ASC treatment presented hair-bearing skin (Fig. 5a (6), b (6)); acute wound with conventional treatment had a common scar (Fig. 5a (3)); however, chronic wound presented unhealing wound (Fig. 5b (3)).

Histopathological evaluations were performed on the acute wound healing of eight Galgo Español dogs, four of whom were treated with conventional treatment and four with ASCs.

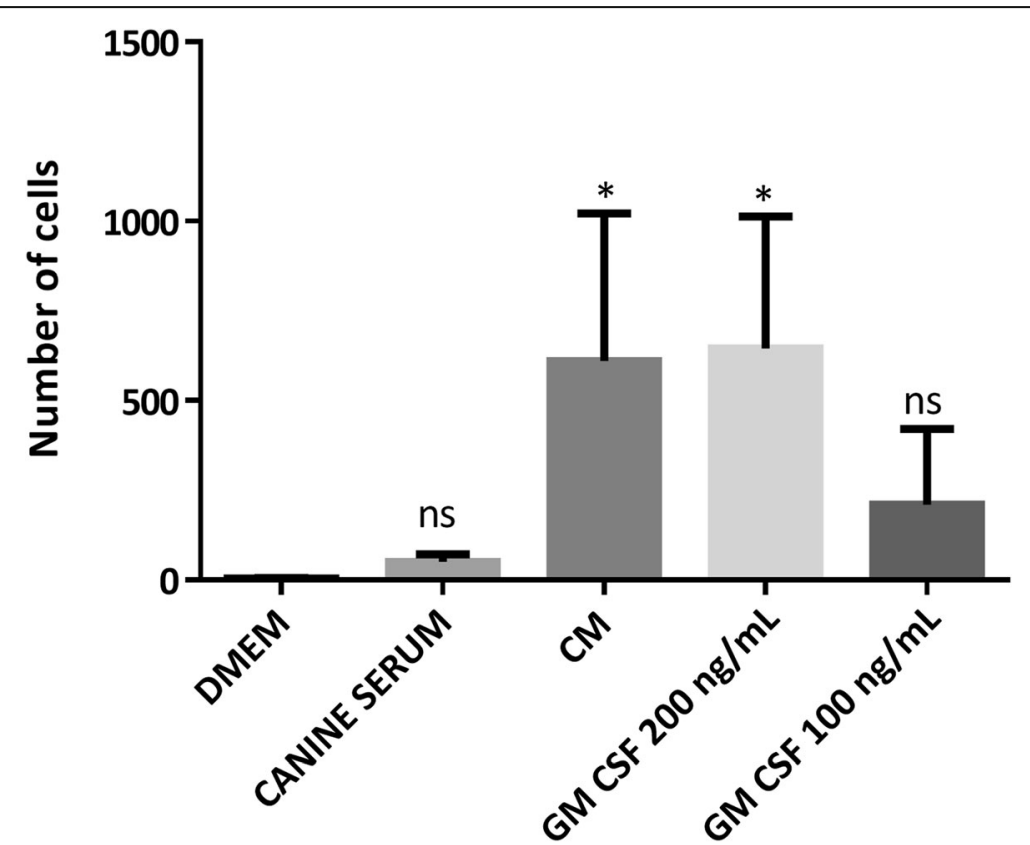

Fig. 2 Transmigration capacity. Quantification of cells migrating toward DMEM, DMEM + canine serum 10\%, conditioned medium (CM), DMEM + GM CSF $200 \mathrm{ng} / \mathrm{ml}$, and DMEM + GM CSF $100 \mathrm{ng} / \mathrm{ml}$. Data represent the mean \pm SD. ${ }^{*} p<0.05$. ns, not significant. $n=3$ different experiments 


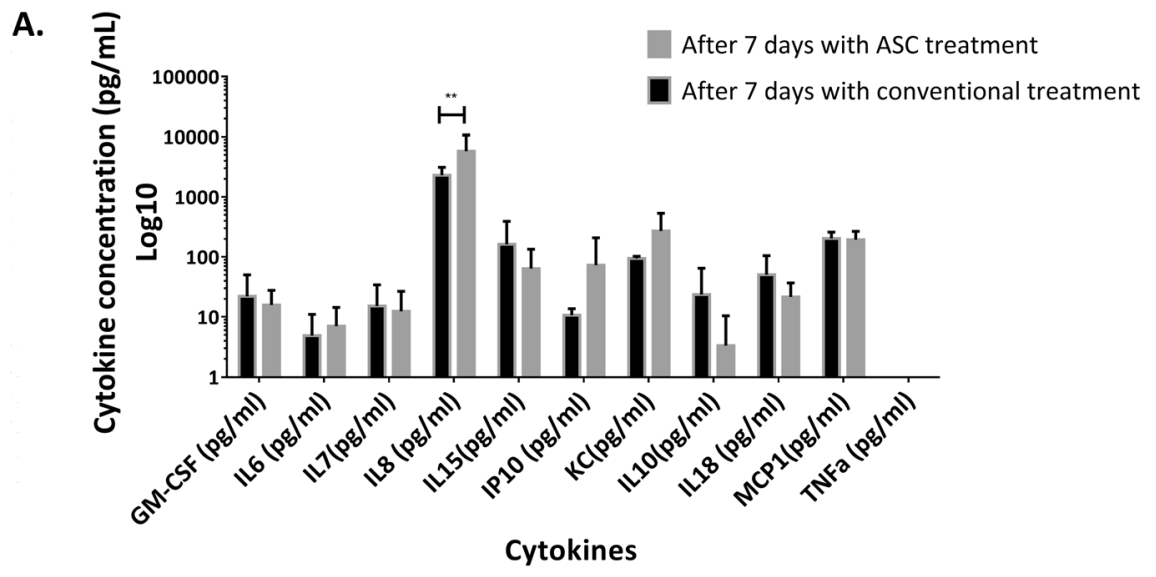

B.

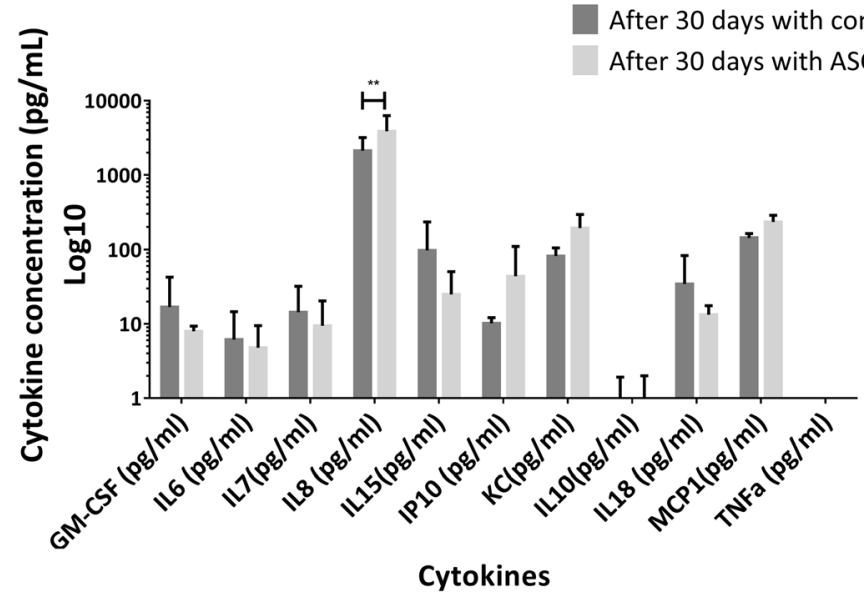

Fig. 3 Cytokine concentration values in dogs using a Milliplex Canine Cytokine Panel. Canine serum levels of conventional and adipose-derived mesenchymal stem cell (ASC) treatment at 7 days (a) and 30 days (b) post-treatment. Values are the mean \pm SD. ${ }^{* *} A$ statistically significant difference of $p<0.01 . n=4-6$ for each experimental point

The epidermis of the wound that received conventional treatment (Fig. 6a (1-3)) exhibited epidermal hyperplasia, hypergranulosis, hyperkeratosis, and ortho- and parakeratosis. The dermis exhibited fibrosis and an abundant mononuclear inflammatory infiltrate extending mainly through the dermis. These findings were consistent with acute dermatitis without follicular components, which is typical of a normal wound healing process. The wounds treated with ASCs (Fig. 6a (4-6)) exhibited relatively normal skin, thin epidermis, orthokeratosis, and fibroblast proliferation. In addition, multiple hair follicles in different stages of activity, collagen fibers, and a slight presence of inflammatory cells were observed in the dermis. The histological characteristics were classified according to the degree of severity: mild, moderate, or marked (Fig. 6b).

\section{Gene expression in the dynamic process of wound} healing

GM-CSF, VEGF-A, MMP-2, and IL-10 genes were evaluated in sixteen patients. Ten dogs with acute wounds were treated with ACS, and six dogs with acute wounds were treated with conventional treatment. To compare our results with normal skin, eight biopsies were taken from healthy dogs. GM-CSF gene expression in dogs treated with ASCs shows an increase of more than 2-fold over wounds after that of conventional treatment with a $p$ value $<0.01$. VEGFA gene expression shows a decrease in ASC-treated dogs with a $p$ value $<$ 0.001 . The expression of the $I L-10$ and $M M P 2$ genes was similar in both treatments. The values were normalized to the TBP gene and were compared to normal skin (Fig. 7).

\section{Discussion}

Wound healing requires a synchronized interplay among cells, growth factors, and extracellular matrix proteins. Several studies have demonstrated that mesenchymal stem cells coordinate the repair response by recruiting other host cells and secreting growth factors and matrix proteins. 


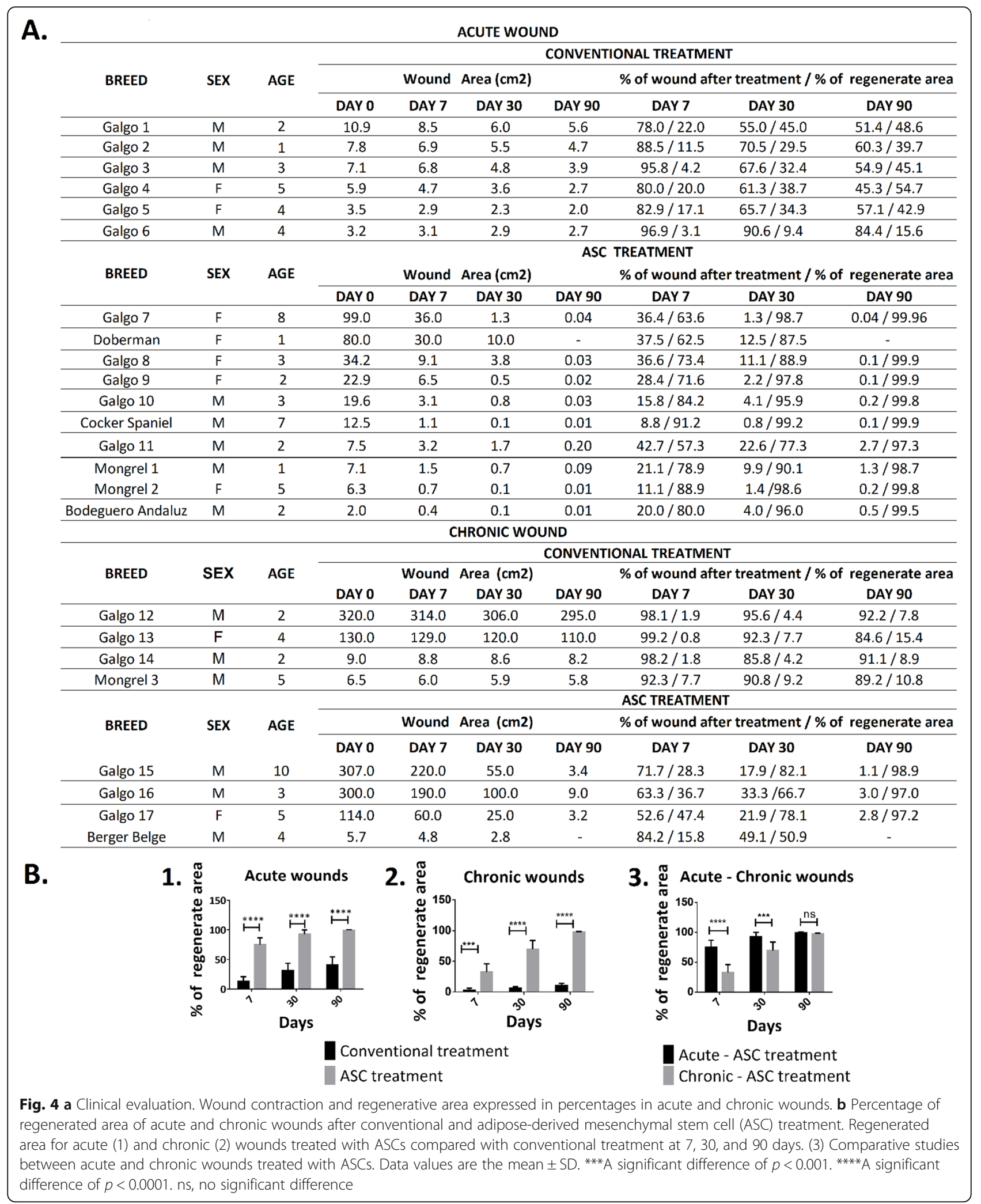

Our study was performed to evaluate the role of allogeneic ASCs in acute and chronic wound healing therapies.
Considering this aim, there are essential characteristics that must be met to allow these cells to be candidates for cell-based therapy. 


\section{ACUTE WOUND HEALING}
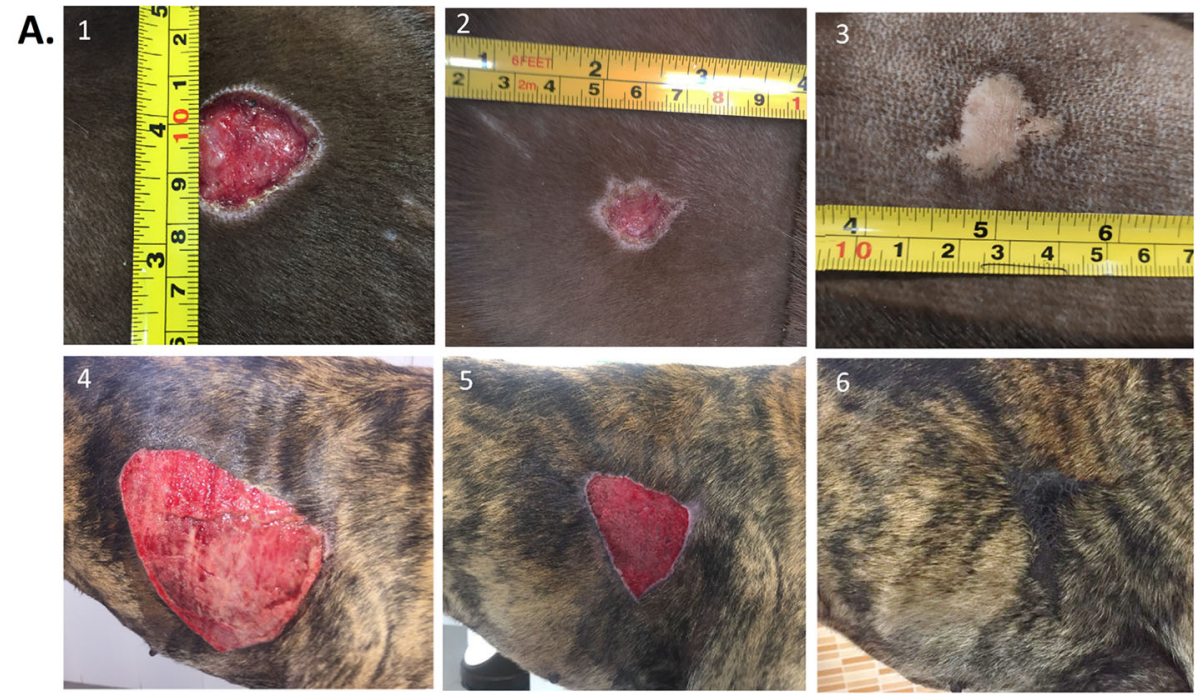

\section{CHRONIC WOUND HEALING}

B.
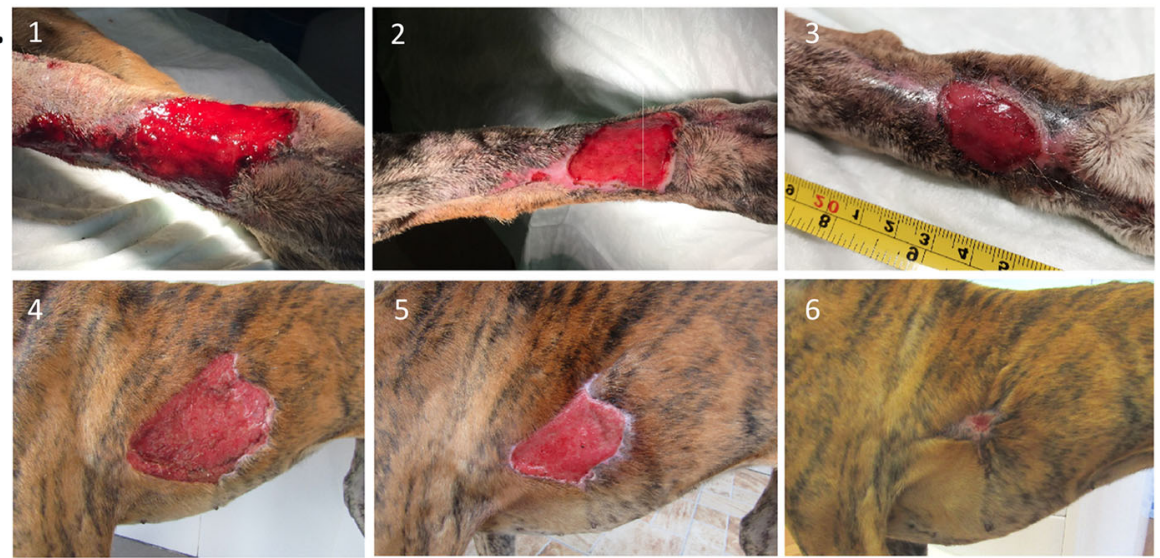

Fig. 5 Re-epithelization of acute (a) and chronic (b) wounds is shown by representative photographs. Dogs with acute and chronic wounds treated with the conventional treatment $(\mathbf{a}(1-3), \mathbf{b}(1-3))$, and dogs treated with adipose-derived mesenchymal stem cells (ASCs) (a (4-6), b (46)) at day 0,7 , and 90

As we have previously mentioned, these cells can differentiate into multiple tissue forming cell lineages. During differentiation, upregulation or suppression of transcription factors occurs via specific signaling pathways. In osteogenic differentiation, Runx2 is a key transcription factor that elevates osteoblast differentiation. Chondrogenic differentiation is driven by Sox 9 , and adipogenic differentiation is mainly controlled by PPAR . We reported the expression of these transcription factor markers involved in the early differentiation of osteoblasts, adipocytes, and chondrocytes, and we presented images of differentiated cells (Fig. 1). These data are in agreement with the study performed by Almalki et al. [14].

As discussed in the "Methods" section, we utilized TBP gene for normalization of qRT-PCR data, according to Rangi et al. [18], who found that TBP has the top position for both geNorm and NormFinder analysis in MSCs, and Vandesompele et al., who found that TBP has the top position for geNorm analysis in skin wound [19].

Particular attention should be given to the homing capability of ASC, allowing the cells to find the way of injury and inflammation. Figure 2 shows the capacity of these cells under normoxic conditions when stimulated by conditioned medium as well as by the inflammatory cytokine GM-CSF to migrate and mediate regenerative effects at sites of tissue damage. The role of conditioned medium in increasing the transmigratory effect of ASCs is noted, which implies that in the process of proliferation, ASCs release factors and cytokines with chemoattractant activity. Enciso et al. [10] demonstrated the expression of MMP-2 and MMP-9 in ASCs enables the breakdown of the endothelial basement membrane. 


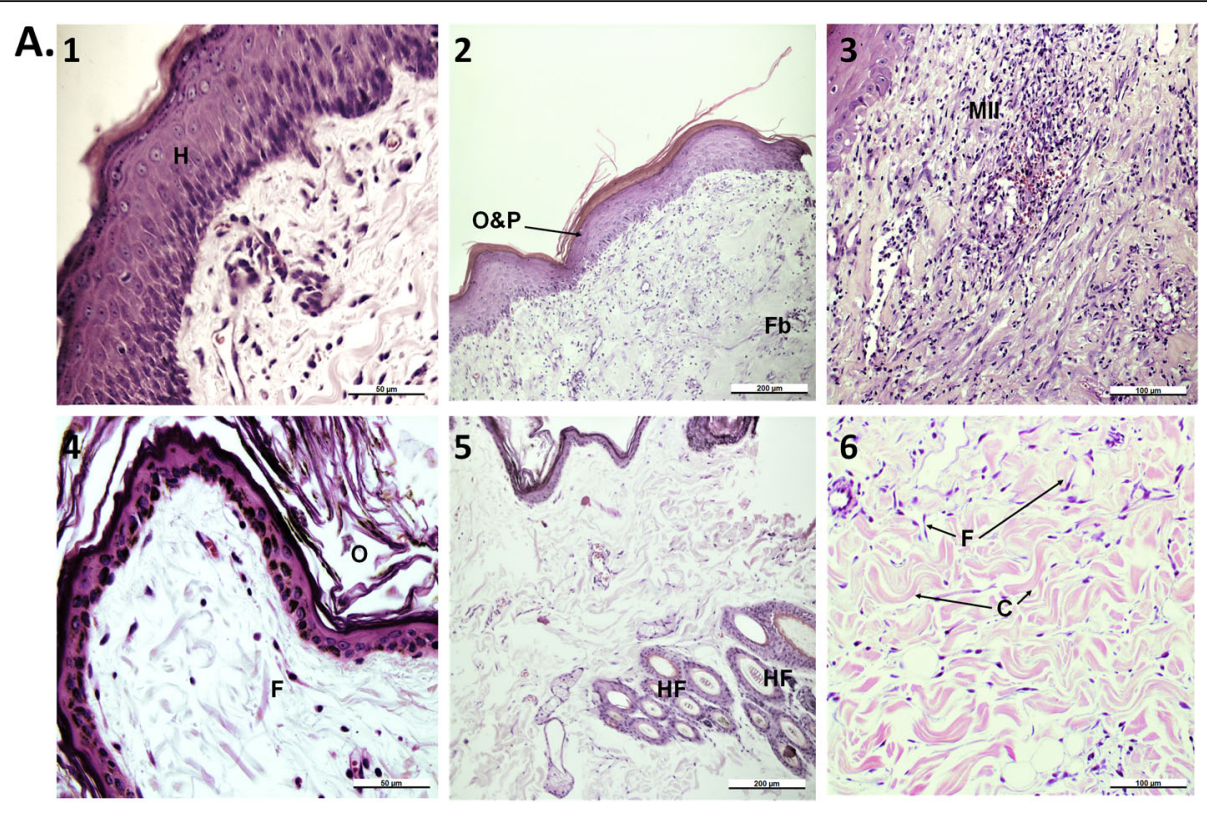

B.

\begin{tabular}{ccc}
\hline \multicolumn{3}{c}{ ACUTE WOUND } \\
\hline \multirow{2}{*}{ HISTOLOGIC APPEARANCES } & CONVENTIONAL TREATMENT & ASC TREATMENT \\
\cline { 2 - 3 } & & 7 DAYS \\
\hline Epiodermal hyperplasia & ++++ & ++ \\
\hline Hyperkeratosis ( orthokeratosis) & ++ & ++ \\
\hline Hyperkeratosis ( parakeratosis) & +++ & - \\
\hline Inflamatory infiltration & ++++ & + \\
\hline Fibroblast proliferation & + & - \\
\hline Fibrosis & +++ & +++ \\
\hline Collagen fibers & + & ++++ \\
\hline Hair follicular & - & $\mathrm{n}=4$ \\
\hline Total animals & $\mathrm{n}=4$ & + \\
\hline
\end{tabular}

Fig. 6 Histopathology of acute wound healing in control and ASC-treated skin wounds at 7 days post-treatment. a Representative photomicrographs demonstrate the histological characteristics of acute healing. H\&E staining (bar length $=50 \mu \mathrm{m})(1$ and 4$), 200 \mu \mathrm{m}(2$ and 5), and $100 \mu \mathrm{m}(3$ and 6$)$. (13) Control; (4-6) ASC-treated. H, hyperplasia; O, orthokeratosis; P, parakeratosis; Fb, fibrosis; MII, mononuclear inflammatory infiltrate; F, fibroblast; HF, hair follicles; C, collagen fibers. b Criteria for histological appearances in acute wounds with conventional treatment and ASC treatment. " $-"$ and " + " $=$ mild, " $++"$ and " $+++"=$ moderate, and " $++++"=$ marked

Our pilot approach, reported by Enciso et al. [57], demonstrated a higher regenerative capacity with earlier and faster closure in wounds treated with ASCs in comparison to other forms of treatment.

In this paper, we extend this previous study to 24 dogs and evaluated the clinical value and safety of the application of cultured adipose allogenic ASCs for treating acute and chronic skin wound healing in the canine model described above.

Damage of the skin certainly induces local inflammation; this process involves multiple mediators, including chemokines, pro- and antiinflammatory cytokines, and growth factors. To analytically evaluate the etiological role of inflammatory processes in systemic compartments, it is necessary to quantify the concentrations of relevant biomarkers in fluids, such as serum.
As shown in Fig. 3, of the cytokines studied, we did not observe increased levels in the serum of dogs treated with ASCs for 7 or 30 days. Although we observed a significant increase in IL-8 cytokine levels in wounds treated with ASCs at both 7 and 30 days, the levels of IL-8 $(3858.64 \mathrm{pg} / \mathrm{ml})$ in the serum of animals at day 30 post-treatment were similar to the median value (3329 $\mathrm{pg} / \mathrm{ml}$ ) of healthy dogs, which is data obtained with the multiplex assay by Safra et al., O'Neill et al., and Kjegaard-Hansen et al. [54, 55]. These results ensure the safety of our protocol, including potential effects on the immune system. This is of great importance when investigating new therapies, especially considering that many descriptive parameters of the dog's immune system are quite similar to those of humans [45].

With respect to the histopathological study, Fig. 5a, b data support the active regenerative process, which 


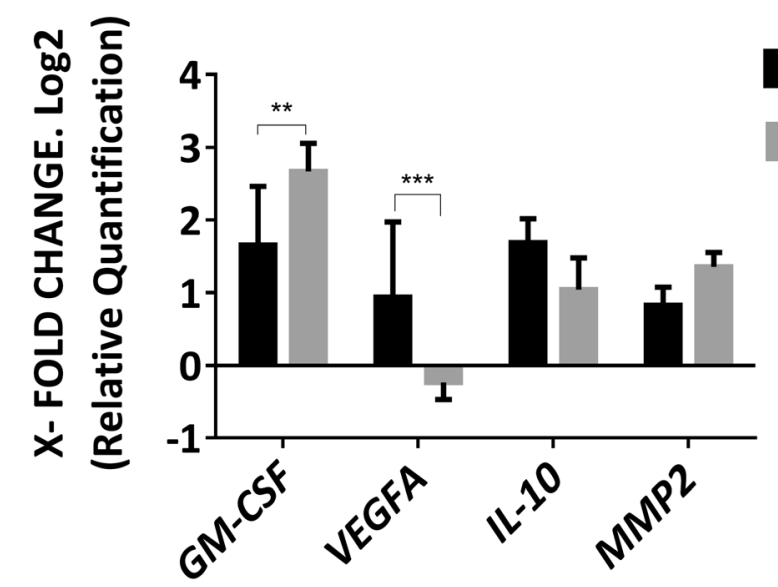

Conventional treatment

ASC treatment

. Relative quantification of gene expression in acute skin wounds after 7 days of conventional and ASC treatments. Data represent mean fold change values in genes \pm SD for both treatments as compared to normal skin. Data values are the mean \pm SD. ${ }^{* *} A$ significant difference of $p<0.01$. ${ }^{* *}$ A significant difference of $p<0.001$

revealed better organization of re-epithelialization, reduced inflammatory infiltrate, marked collagen fibers, and the presence of multiple hair follicles in different stages of activity on day 7 after treatment with ASCs by promoting epidermal and dermal regeneration.

These data indicate the success of allogeneic ASCs in wound healing therapy, providing faster wound healing and re-epithelization than that of other treatments.

Ribeiro et al. showed that the use of allogeneic MSC in chronic wounds in dogs was effective; however, unlike our study, at the end of the evaluation, they had the presence of scarring [58]. This may have been due to the fact that they used a low dose of stem cells $\left(1 \times 10^{5} / \mathrm{cm}^{2}\right)$ compared to our study where we used $3 \times 10^{6} / \mathrm{cm}^{2}$ and obtained a regeneration of the skin with characteristics similar to normal skin as well as reduction of scar formation.

Many clinical trials in wounds showed that the use of ASC therapy alone or combined with other compounds, such as platelet-rich plasma (PRP), hyaluronic acid, and others, can stimulate cutaneous wound healing [3, 5, 59-61], achieving good and fast healing with the final presence of a scar; however, in our study, we observed that the skin regenerates with similar characteristics to the normal skin and presents a small scar and that with time the epithelium will become normal following the repair process as mentioned by Nuschke et al. [62]. However, there are clinical studies that use autologous fat grafting to correct wound scars, demonstrating that they are able to stimulate the regeneration process [63-65].

The therapeutic potential of autologous MSCs has been demonstrated, both in preclinical and clinical studies, in different pathologies. However, in many occasions, the use of autologous transplantation can have some limitations regarding to the MSC production, the method for therapy, the delivered dose, the stage of the disease, and the status and/or genetic receptivity of the patient $[66,67]$.

On the other hand, recent clinical studies have demonstrated therapeutic efficacy in androgenic alopecia, obtaining greater hair density by transplanting autologous ASC, PRP, stromal vascular fraction (SVF), and micrografts containing mesenchymal stem cells from the hair follicle [68-71] and also by topical use [72]. These interesting results would allow the possibility of using our methodology in pathologies in which the hair follicle is damaged or absent.

As outlined above, the consideration of using autologous or allogenic mesenchymal cells is still under discussion. This approach must be done in terms of the clinical benefit that will be obtained. From our point of view, allogeneic mesenchymal cell therapy is of great value in the tissue regeneration process.

In this study, we analyzed the gene expression of IL10, $M M P-2$, GM-CSFF, and VEGFA in the process of cutaneous wound healing in a canine model treated with allogeneic ASCs. These gene products have important biological effects on wound healing [23, 73].

It is well known that the process of wound healing is an organized event resulting in the restoration of the skin. It involves the interactions of many different cell types, matrix components, and biochemical factors. In this context, the GM-CSF gene is a possible candidate for the regulation of wound healing because it is synthesized by a number of cells involved in the repair process [74-76].

Consistent with these comments, we found an upregulation of GM-CSF at the gene level in our canine model treated with ASCs. GM-CSF has been shown to 
exert beneficial effects on wound healing in patients suffering from poorly healing wounds and chronic skin ulcers with diverse etiology [23, 77].

Considering the role of GM-CSF in transmigration (Fig. 2), the increased gene expression levels of GM-CSF may contribute to the recruitment of cells that participate in skin repair to the site of injury.

However, for $I L-10$ and $M M P-2$ genes, there were no significant differences between treatments and between them; a possible explanation is that IL-10 regulates MMP-2 expression [73, 78].

With respect to VEGFA gene, we expected an increase in gene expression, taking into consideration the histological findings which revealed better organization of re-epithelialization; on the contrary, a significant decrease was found at day 10 post-initial wounding. Ebrahimian et al. demonstrated that ASC treatment promotes angiogenesis and accelerates wound healing by producing VEGF protein [79]. He showed an increase in VEGF on day 7 after wound initiation, while on day 10, the VEGF value decreased, which is similar to our results. On the other hand, Kanji et al. hypothesize that MSCs would behave like pericytes, which stabilize blood vessel formation [80].

In view of the data we present in this study, we suggest that the beneficial effects observed in canine wounds after allogenic ASC therapy are due not only to direct ASC action but also to indirect paracrine processes through the induction of secondary factors involved in wound repair.

\section{Conclusion}

To the best of our knowledge, the study we have developed in this paper represents, for the first time, a cell therapy with allogeneic ASCs in patients with acute and chronic wounds. It is important to note the clinical safety of our protocol; an important conclusion is that this study represents a translational model for human wound research with respect to tissue regeneration. The development of an allogeneic ASC therapy to improve wound healing could have clinical impacts for both dogs and people.

\begin{abstract}
Abbreviations
ARRIVE: Animal Research: Reporting In Vivo Experiments; ASCs: Adipose mesenchymal stem cells; AT: Adipose tissue; CM: Conditioned medium; GMCSF: Granulocyte-macrophage colony stimulating factor; HGs: Housekeeping genes; IL-6: Interleukin-6; IL-7: Interleukin-7; IL-8: Interleukin-8; IL10: Interleukin-10; IL-15: Interleukin-15; IL-18: Interleukin-18; IP-10: Interferon $\gamma$-inducible protein-10; KC: Keratinocyte chemoattractant; MCP-1: Monocyte chemoattractant protein-1; MSCs: Mesenchymal stem cells; PBS: Phosphatebuffered saline; PRP: Platelet-rich plasma; SVF: Stromal vascular fraction; TNFa: Tumor necrosis factor a
\end{abstract}

\section{Acknowledgements}

We thank Flow Cytometry, Genomics and Proteomics UCM facilities, for their technical support.

\section{Authors' contributions}

$\mathrm{NE}$ and $\mathrm{CT}$ contributed to the collection of data, data analysis and interpretation, and writing of the manuscript. LA participated in the collection and interpretation of data. MLF and CF participated in the collection of data. All authors read and approved the final manuscript.

\section{Funding}

Nathaly Enciso was supported by the National Fund, for Scientific, Technological, and Technological Innovation Development (FONDECYT), the funding branch of the National Council for Science, Technological, and Technological Innovation Development (CONCYTEC) Peru (grant contract no. 041-2016-FONDECYT).

\section{Availability of data and materials}

The datasets generated and/or analyzed during the current study are available from the corresponding author on reasonable request.

\section{Ethics approval and consent to participate}

Dogs used in this study were treated according to the Spanish (Real Decreto 53/2013) and European Community legislation for the care of experimental animals, and all procedures dealing with animal care, handling, and sampling were approved by the ethical committee of our institution (approval no. 08/ 2017). In addition, the dog owners signed an informed consent form accepting this treatment.

\section{Consent for publication}

Not applicable.

\section{Competing interests}

The authors declare they have no competing interests.

\section{Author details}

1"Experimental Hematology" UCM-Research Group, Veterinary Faculty, Complutense University of Madrid, Avda Puerta de Hierro s/n, 28040 Madrid, Spain. ${ }^{2}$ Department of Biochemistry and Molecular Biology, Veterinary Faculty, Complutense University of Madrid, Avda Puerta de Hierro s/n, 28040 Madrid, Spain. ${ }^{3}$ Department of Animal Surgery and Medicine, Veterinary Faculty, Complutense University of Madrid, Avda Puerta de Hierro s/n, 28040 Madrid, Spain.

Received: 5 May 2020 Revised: 31 May 2020

Accepted: 18 June 2020 Published online: 29 June 2020

\section{References}

1. Hendijani F. Explant culture: An advantageous method for isolation of mesenchymal stem cells from human tissues. Cell proliferation. 2017;50: e12334.

2. Alstrup T, Eijken M, Bohn AB, Møller B, Damsgaard TE. Isolation of adipose tissue-derived stem cells: enzymatic digestion in combination with mechanical distortion to increase adipose tissue-derived stem cell yield from human aspirated fat. Curr Protoc Stem Cell Biol. 2019;48:e68.

3. Gentile P, Garcovich S. Concise review: adipose-derived stem cells (ASCs) and adipocyte-secreted exosomal microRNA (A-SE-miR) modulate cancer growth and promote wound repair. J Clin Med. 2019:8:855.

4. Gentile P, Calabrese C, De Angelis B, Pizzicannella J, Kothari A, Garcovich S. Impact of the different preparation methods to obtain human adiposederived stromal vascular fraction cells (AD-SVFs) and human adiposederived mesenchymal stem cells (AD-MSCs): enzymatic digestion versus mechanical centrifugation. Int J Mol Sci. 2019;20:5471.

5. Gentile P, Orlandi A, Scioli MG, Di Pasquali C, Bocchini I, Cervelli V. Concise review: adipose-derived stromal vascular fraction cells and platelet-rich plasma: basic and clinical implications for tissue engineering therapies in regenerative surgery. Stem Cells Transl Med. 2012;1:230-6.

6. Chen S-H, Kuan T-S, Kao M-J, Wu W-T, Chou L-W. Clinical effectiveness in severe knee osteoarthritis after intra-articular platelet-rich plasma therapy in association with hyaluronic acid injection: three case reports. Clin Interv Aging. 2016;11:1213-9.

7. Guadix JA, Zugaza JL, Galvez-Martin P. Characteristics, applications and prospects of mesenchymal stem cells in cell therapy. Med Clin (Barc). 2017; 148:408-14. 
8. Wang SG, Hsu NC, Wang SM, Wang FN. Successful treatment of plaque psoriasis with allogeneic gingival mesenchymal stem cells: a case study. Case Rep Dermatol Med 2020;2020:4617520-20.

9. Podestà MA, Remuzzi G, Casiraghi F. Mesenchymal stromal cells for transplant tolerance. Front Immunol 2019;10:1287-87.

10. Enciso N, Ostronoff LLK, Mejias G, Leon LG, Fermin ML, Merino E, et al. Stem cell factor supports migration in canine mesenchymal stem cells. Vet Res Commun. 2018;42:29-38,

11. Neupane M, Chang CC, Kiupel M, Yuzbasiyan-Gurkan V. Isolation and characterization of canine adipose-derived mesenchymal stem cells. Tissue Eng Part A. 2008;14:1007-15.

12. Csaki C, Matis U, Mobasheri A, Shakibaei M. Co-culture of canine mesenchymal stem cells with primary bone-derived osteoblasts promotes osteogenic differentiation. Histochem Cell Biol. 2009;131:251-66.

13. Vieira NM, Brandalise V, Zucconi E, Secco M, Strauss BE, Zatz M. Isolation, characterization, and differentiation potential of canine adipose-derived stem cells. Cell Transplant. 2010:19:279-89.

14. Almalki SG, Agrawal DK. Key transcription factors in the differentiation of mesenchymal stem cells. Differentiation. 2016:92:41-51.

15. Bae HK, Jung BD, Lee S, Park CK, Yang BK, Cheong HT. Correlation of spontaneous adipocyte generation with osteogenic differentiation of porcine skin-derived stem cells. J Vet Sci. 2019;20:16-26.

16. Marmotti A, Mattia S, Castoldi F, Barbero A, Mangiavini L, Bonasia DE, et al. Allogeneic umbilical cord-derived mesenchymal stem cells as a potential source for cartilage and bone regeneration: an in vitro study. Stem Cells Int. 2017;2017:1732094.

17. James AW. Review of signaling pathways governing MSC osteogenic and adipogenic differentiation. Scientifica (Cairo). 2013;2013:684736.

18. Ragni E, Vigano M, Rebulla P, Giordano R, Lazzari L. What is beyond a qRTPCR study on mesenchymal stem cell differentiation properties: how to choose the most reliable housekeeping genes. J Cell Mol Med. 2013;17:16880.

19. Vandesompele J, De Preter K, Pattyn F, Poppe B, Van Roy N, De Paepe A, et al. Accurate normalization of real-time quantitative RT-PCR data by geometric averaging of multiple internal control genes. Genome Biol. 2002; 3:Research0034.

20. Ho J, Walsh C, Yue D, Dardik A, Cheema U. Current advancements and strategies in tissue engineering for wound healing: a comprehensive review. Adv Wound Care (New Rochelle). 2017;6:191-209.

21. Gantwerker EA, Hom DB. Skin: histology and physiology of wound healing Clin Plast Surg. 2012;39:85-97.

22. Sorg H, Tilkorn DJ, Hager S, Hauser J, Mirastschijski U. Skin wound healing: an update on the current knowledge and concepts. Eur Surg Res. 2017;58:81-94.

23. Barrientos S, Brem H, Stojadinovic O, Tomic-Canic M. Clinical application of growth factors and cytokines in wound healing. Wound Repair Regen. 2014; 22:569-78.

24. Eming SA, Martin P, Tomic-Canic M. Wound repair and regeneration: mechanisms, signaling, and translation. Sci Transl Med. 2014;6:265sr6.

25. Qing C. The molecular biology in wound healing \& non-healing wound. Chin J Traumatol. 2017;20:189-93.

26. Wang PH, Huang BS, Horng HC, Yeh CC, Chen YJ. Wound healing. J Chin Med Assoc. 2018:81:94-101.

27. Han G, Ceilley R. Chronic wound healing: a review of current management and treatments. Adv Ther. 2017;34:599-610.

28. Lee DE, Ayoub N, Agrawal DK. Mesenchymal stem cells and cutaneous wound healing: novel methods to increase cell delivery and therapeutic efficacy. Stem Cell Res Ther. 2016;7:37.

29. Gaur M, Dobke M, Lunyak W. Mesenchymal Stem Cells from Adipose Tissue in Clinical Applications for Dermatological Indications and Skin Aging. Int J Mol Sci. 2017:18:208.

30. Guo J, Hu H, Gorecka J, Bai H, He H, Assi R, et al. Adipose-derived mesenchymal stem cells accelerate diabetic wound healing in a similar fashion as bone marrow-derived cells. Am J Physiol Cell Physiol. 2018;315: C885-C96.

31. Chang YW, Wu YC, Huang SH, Wang HD, Kuo YR, Lee SS. Autologous and not allogeneic adipose-derived stem cells improve acute burn wound healing. PLoS One. 2018;13:e0197744.

32. Broeckx SY, Borena BM, Van Hecke L, Chiers K, Maes S, Guest DJ, et al. Comparison of autologous versus allogeneic epithelial-like stem cell treatment in an in vivo equine skin wound model. Cytotherapy. 2015;17: $1434-46$.
33. Fu Y, Karbaat L, Wu L, Leijten J, Both SK, Karperien M. Trophic effects of mesenchymal stem cells in tissue regeneration. Tissue Eng Part B Rev. 2017; 23:515-28.

34. Monsuur HN, Boink MA, Weijers EM, Roffel S, Breetveld M, Gefen A, et al. Methods to study differences in cell mobility during skin wound healing in vitro. J Biomech. 2016:49:1381-7.

35. Szydlak R. Mesenchymal stem cells' homing and cardiac tissue repair. Acta Biochim Pol. 2019:66:483-9.

36. Guest DJ, Smith MR, Allen WR. Equine embryonic stem-like cells and mesenchymal stromal cells have different survival rates and migration patterns following their injection into damaged superficial digital flexor tendon. Equine Vet J. 2010;42:636-42.

37. Oh EJ, Lee HW, Kalimuthu S, Kim TJ, Kim HM, Baek SH, et al. In vivo migration of mesenchymal stem cells to burn injury sites and their therapeutic effects in a living mouse model. J Control Release. 2018:279:7988.

38. Park BN, Lim TS, Yoon JK, An YS. In vivo tracking of intravenously injected mesenchymal stem cells in an Alzheimer's animal model. Cell Transplant. 2018;27:1203-9.

39. Singer NG, Caplan Al. Mesenchymal stem cells: mechanisms of inflammation. Annu Rev Pathol. 2011:6:457-78.

40. Motegi SI, Ishikawa O. Mesenchymal stem cells: the roles and functions in cutaneous wound healing and tumor growth. J Dermatol Sci. 2017;86:83-9.

41. Maranda EL, Rodriguez-Menocal L, Badiavas EV. Role of mesenchymal stem cells in dermal repair in burns and diabetic wounds. Curr Stem Cell Res Ther. 2017;12:61-70.

42. Martinello T, Gomiero C, Perazzi A, lacopetti I, Gemignani F, DeBenedictis GM, et al. Allogeneic mesenchymal stem cells improve the wound healing process of sheep skin. BMC Vet Res. 2018;14:202.

43. Ankrum JA, Ong JF, Karp JM. Mesenchymal stem cells: immune evasive, not immune privileged. Nat Biotechnol. 2014;32:252-60.

44. Barberini DJ, Aleman M, Aristizabal F, Spriet M, Clark KC, Walker NJ, et al. Safety and tracking of intrathecal allogeneic mesenchymal stem cell transplantation in healthy and diseased horses. Stem Cell Res Ther. 2018;9: 96.

45. Felsburg PJ. Overview of immune system development in the dog: comparison with humans. Hum Exp Toxicol. 2002;21:487-92.

46. Dehoux JP, Gianello P. The importance of large animal models in transplantation. Front Biosci. 2007;12:4864-80.

47. Volk SW, Bohling MW. Comparative wound healing--are the small animal veterinarian's clinical patients an improved translational model for human wound healing research? Wound Repair Regen. 2013;21:372-81.

48. Russell KA, Chow NH, Dukoff D, Gibson TW, LaMarre J, Betts DH, et al. Characterization and immunomodulatory effects of canine adipose tissueand bone marrow-derived mesenchymal stromal cells. PLoS One. 2016;11: e0167442.

49. Dominici M, Le Blanc K, Mueller I, Slaper-Cortenbach I, Marini F, Krause D, et al. Minimal criteria for defining multipotent mesenchymal stromal cells. The International Society for Cellular Therapy position statement. Cytotherapy. 2006;8:315-7.

50. Farghali HA, AbdEIKader NA, Khattab MS, AbuBakr HO. Evaluation of subcutaneous infiltration of autologous platelet-rich plasma on skin-wound healing in dogs. Biosci Rep. 2017:37: BSR20160503.

51. Koressaar T, Remm M. Enhancements and modifications of primer design program Primer3. Bioinformatics. 2007:23:1289-91.

52. Turabelidze A, Guo S, DiPietro LA. Importance of housekeeping gene selection for accurate reverse transcription-quantitative polymerase chain reaction in a wound healing model. Wound Repair Regen. 2010;18:460-6.

53. Veterinary Co-operative Oncology Group - Common Terminology Criteria for Adverse Events (VCOG-CTCAE) following chemotherapy or biological antineoplastic therapy in dogs and cats v1.0. Vet Comp Oncol. 2004;2:195-213.

54. O'Neill S, Drobatz K, Satyaraj E, Hess R. Evaluation of cytokines and hormones in dogs before and after treatment of diabetic ketoacidosis and in uncomplicated diabetes mellitus. Vet Immunol Immunopathol. 2012;148: 276-83.

55. Kjelgaard-Hansen M, Goggs R, Wiinberg B, Chan DL. Use of serum concentrations of interleukin-18 and monocyte chemoattractant protein-1 as prognostic indicators in primary immune-mediated hemolytic anemia in dogs. J Vet Intern Med. 2011;25:76-82.

56. Safra N, Hitchens PL, Maverakis E, Mitra A, Korff C, Johnson E, et al. Serum levels of innate immunity cytokines are elevated in dogs with metaphyseal 
osteopathy (hypertrophic osteodytrophy) during active disease and remission. Vet Immunol Immunopathol. 2016;179:32-5.

57. Enciso N, Avedillo L, Fermin ML, Fragio C, Tejero C. Regenerative potential of allogeneic adipose tissue-derived mesenchymal cells in canine cutaneous wounds. Acta Vet Scand. 2020;62:13.

58. Ribeiro J, Pereira T, Amorim I, Caseiro AR, Lopes MA, Lima J, et al. Cell therapy with human MSCs isolated from the umbilical cord Wharton jelly associated to a PVA membrane in the treatment of chronic skin wounds. Int J Med Sci. 2014;11:979-87.

59. Cervelli V, Lucarini L, Spallone D, Palla L, Colicchia GM, Gentile P, et al. Use of platelet-rich plasma and hyaluronic acid in the loss of substance with bone exposure. Adv Skin Wound Care. 2011;24:176-81.

60. Gentile P, Colicchia GM, Nicoli F, Cervelli G, Curcio CB, Brinci L, et al. Complex abdominal wall repair using a porcine dermal matrix. Surg Innov. 2013:20:Np12-5.

61. Gentile P, Scioli MG, Bielli A, Orlandi A, Cervelli V. Comparing different nanofat procedures on scars: role of the stromal vascular fraction and its clinical implications. Regen Med. 2017;12:939-52.

62. Nuschke A. Activity of mesenchymal stem cells in therapies for chronic skin wound healing. Organogenesis. 2014;10:29-37.

63. Gentile P, Scioli MG, Orlandi A, Cervelli V. Breast reconstruction with enhanced stromal vascular fraction fat grafting: what is the best method? Plast Reconstr Surg Glob Open. 2015:3:e406.

64. Gentile P, De Angelis B, Pasin M, Cervelli G, Curcio CB, Floris M, et al. Adipose-derived stromal vascular fraction cells and platelet-rich plasma: basic and clinical evaluation for cell-based therapies in patients with scars on the face. J Craniofac Surg. 2014;25:267-72.

65. Gentile P, Casella D, Palma E, Calabrese C. Engineered Fat Graft Enhanced with Adipose-Derived Stromal Vascular Fraction Cells for Regenerative Medicine: Clinical, Histological and Instrumental Evaluation in Breast Reconstruction. J Clin Med. 2019;8:504.

66. Lukomska B, Stanaszek L, Zuba-Surma E, Legosz P, Sarzynska S, Drela K. Challenges and controversies in human mesenchymal stem cell therapy. Stem Cells Int. 2019;2019:9628536.

67. Pittenger MF, Discher DE, Péault BM, Phinney DG, Hare JM, Caplan Al. Mesenchymal stem cell perspective: cell biology to clinical progress. NP. Regen Med 2019;4:22-22.

68. Gentile P, Scioli MG, Cervelli V, Orlandi A, Garcovich S. Autologous micrografts from scalp tissue: trichoscopic and long-term clinical evaluation in male and female androgenetic alopecia. Biomed Res Int. 2020;2020: 7397162.

69. Gentile P, Scioli MG, Bielli A, Orlandi A, Cervelli V. Stem cells from human hair follicles: first mechanical isolation for immediate autologous clinical use in androgenetic alopecia and hair loss. Stem Cell Investig. 2017;4:58.

70. Gentile P, Garcovich S. Advances in Regenerative Stem Cell Therapy in Androgenic Alopecia and Hair Loss: Wnt pathway, Growth-Factor, and Mesenchymal Stem Cell Signaling Impact Analysis on Cell Growth and Hair Follicle Development. Cells. 2019;8:466.

71. Gentile P. Autologous Cellular Method Using Micrografts of Human Adipose Tissue Derived Follicle Stem Cells in Androgenic Alopecia. Int J Mol Sci. 2019;20:3446.

72. Tak YJ, Lee SY, Cho AR, Kim YS. A randomized, double-blind, vehiclecontrolled clinical study of hair regeneration using adipose-derived stem cell constituent extract in androgenetic alopecia. Stem Cells Transl Med. 2020;1-11. https://doi.org/10.1002/sctm.19-0410.

73. Xiao S, Huang G, Wei Z, Nie K, Liu Z, Deng C, et al. IL-10 gene-modified human amniotic mesenchymal stem cells augment regenerative wound healing by multiple synergistic effects. Stem Cells Int 2019;2019:9158016-16.

74. Caux C, Dezutter-Dambuyant C, Schmitt D, Banchereau J. GM-CSF and TNFalpha cooperate in the generation of dendritic Langerhans cells. Nature. 1992;360:258-61.

75. Dedhar S, Gaboury L, Galloway P, Eaves C. Human granulocyte-macrophage colony-stimulating factor is a growth factor active on a variety of cell types of nonhemopoietic origin. Proc Natl Acad Sci U S A. 1988;85:9253-7.

76. Braunstein S, Kaplan G, Gottlieb AB, Schwartz M, Walsh G, Abalos RM, et al. GM-CSF activates regenerative epidermal growth and stimulates keratinocyte proliferation in human skin in vivo. J Invest Dermatol. 1994;103: $601-4$

77. Cianfarani F, Tommasi R, Failla CM, Viviano MT, Annessi G, Papi M, et al. Granulocyte/macrophage colony-stimulating factor treatment of human chronic ulcers promotes angiogenesis associated with de novo vascular endothelial growth factor transcription in the ulcer bed. Br J Dermatol. 2006;154:34-41.

78. Stearns ME, Wang M, Hu Y, Garcia FU, Rhim J. Interleukin 10 blocks matrix metalloproteinase-2 and membrane type 1-matrix metalloproteinase synthesis in primary human prostate tumor lines. Clin Cancer Res. 2003;9: 1191-9.

79. Ebrahimian TG, Pouzoulet F, Squiban C, Buard V, André M, Cousin B, et al. Cell therapy based on adipose tissue-derived stromal cells promotes physiological and pathological wound healing. Arterioscler Thromb Vasc Biol. 2009;29:503-10.

80. Kanji S, Das H. Advances of stem cell therapeutics in cutaneous wound healing and regeneration. Mediat Inflamm. 2017;2017:5217967.

\section{Publisher's Note}

Springer Nature remains neutral with regard to jurisdictional claims in published maps and institutional affiliations.
Ready to submit your research? Choose BMC and benefit from:

- fast, convenient online submission

- thorough peer review by experienced researchers in your field

- rapid publication on acceptance

- support for research data, including large and complex data types

- gold Open Access which fosters wider collaboration and increased citations

- maximum visibility for your research: over $100 \mathrm{M}$ website views per year

At BMC, research is always in progress.

Learn more biomedcentral.com/submissions 